varying in diameter from 2 to 10 micro-millimetres, usually in several layers, other endophyllic hyphæ penetrating from them into the root between the epidermal cells, these being still slenderer than those of the envelope. By this structure, the formation by the tree of root-hairs is entirely prevented, and it is through it alone that nutriment is absorbed out of the soil. It makes its appearance first on Jateral roots of the young seedling, and is constantly being replaced by fresh formations on older roots. Dr. Frank found this Mycorhiza invariably present on every root examined of trees belonging to the Cupuliferæ, also occasionally on Salicaceæ and Coniferæ, but not on woody plants belonging to other natural orders, nor on any herbaceous plant. He also regards the phenomenon as an example of symbiosis, comparable in all essential points to that of lichens, the Mycorhiza corresponding to the fungal element, the tree itself to the algal gonidia. Dr. Woronin confirms these statements in relation to Coniferæ, Salicaceæ, and som o other trees, and thinks it probable that the fungus is the mycelium of a Boletus. He regards it, however, as truly parasitic.

In the discussion which took place at Strassburg, Dr. Frank stated that the fact of this phenomenon having been observed especially in the Cupuliferæ, was probably due to the partiality of these trees for soil rich in humus. $\mathrm{He}$ had observed it also in the Abietineæ among Coniferæ, the Salicacex, the alder and birch among Betulaceæ, and in one instance each in the lime and blackthorn. He regards it as probably much more widely diffused than previous observations had sugyested. Prof. de Bary, who accepts the explanation of the phenonenon as an example of symbiosis, pointed out that a similar relationship has long been known between Orchideæ and fungus hyphæ. Observations in the same direction have also been made by Riess and Janczewski.

ALFRED W. BENNETT

\section{NORWEGIAN TOADSTOOLS}

$A$ MONG the various interesting facts regarding the history of cryptogamic plants given in the new edition of Prof. Schübeler's great work on the flora of Norway, special interest attaches to the results of his experiments on Amanita muscaria, one of the commonest of the Norwegian toadstools. According to Dr. Schubeler, we have in this mushroom the source whence the ancient Scandinavians derived a preparation whose intoxicating and half poisonous properties induced symptoms of frenzied excitement, similar in all respects to those exhibited by the old northern warriors when taking part in a "Berserksgang," which appears to have been very similar to the so-called "running amok." Prof. Schübeler founds his opinion on the evidence given by the Russian writers, Krascheninnikow, Erman, and others, as to the effects produced on the Kamchatkans by a decoction of the Amanita, which they used as an intoxicating drink until they were brought into closer contact with the Russians, from whom they have acquired the practice of drinking spirits. In the present day this use of the Amanita seems to be limited to the nomadic Korjakes, with whom the neighbouring Kamchatkan tribes carry on a profitable trade, giving only one or two of these mushrooms in exchange for a reindeer. According to the testimony of the Kamchatkans, the first symptom noticed after drinking this so-called "Muchamór liqueur," one of whose ingredients is said to be the juice of Epilobium angustifolium, is a trembling in the limbs, followed after a time by great flushing of the face and general excitement and irritability, which in the case of many is accompanied with an abnormal increase of muscular force. Thus an instance is recorded in which a man while under the influence of this stimulant ran I5 versts carrying a sack of flour on his back weighing 120 lbs., which in his ordinary condition he could barely lift. On comparing the symptoms of intoxication by muchamor recorded among the nomads of North-Eastern Asia with the accounts given by Icelandic and other northern authorities of the condition of the Berserkers in their frenzy, Dr. Schübeler-finds such complete harmony that there can be no doubt of the identity of the causes to which both may be referred. We know, moreover, that while the descriptions of the Berserkergang forcibly recall the frenzy induced by the use of hachish, or opium, neither of these stimulants could have been attainable in Iceland in ancient times, nor could brandy have been used by the northmen, since it was not introduced into Norway before 153I. The employment of mead or ale by the Bersekers is equally negatived by the symptoms recorded, which the writer seems to have traced beyond a doubt to their true source. It is worthy of notice that as early as the beginning of the eleventh century the law-givers of Iceland recognised the Berserkergang as a manifestation of frenzy, for which the actors were to be held accountable, while a law was introduced in I I 23 which ordained that every man who took part in these outbreaks should be banished from the island for three years, and that a sim:lar punishment should be awarded to all who were present and who did not help to bind the Berserkers and watch over them till their excitement had passed away.

\section{SCIENTIFIC SERIALS}

Bulletin de l'Académie royale de Belgique, October ro.Note on the crepuscular lights observed towards the end of the year 1883 , by M. Hirn. A new explanation is here suggested of this phenomenon, which is attributed to a highly electric condition of the upper atmospheric layers in combination with particles of matter floating round the globe, and possibly due to the Krakatoa eruption. - On the notion of force in modern science, by M. Hirn. In this essay force is removed from the almost mystic domain it has hitherto occupied, and brought within the sphere of actual experience. The question to be determined by science is, whether gravitation, electricity, heat, \&c., are to be regarded as distinct entities, or different forms of the same element absolutely distinct from what we call ponderable matter. But owing to the prevailing confusion regarding the nature of force, it is better for the present to study its various dynamic manifestations, than to attempt to reduce them to one element.-Analysis of some rocks from the "rivers of stone" in the Falkland Islands, by A. Renard. Amongst these specimens is a square prism with regular polyhedric breakage showing a granitoid texture, and altogether typical of the eruptive masses frequently interspersed amongst Palæozoic formations like those of the Falkland Islands. This fragment must be classed in the group of diabase rocks, and may serve to throw some light on the origin of the remarkable "rivers of stone" described by Darwin and Wyville Thomson. - Note on the gemmation of the channels in the planet Mars, by $\mathrm{F}$. Terby. It is suggested that this curious phenomenon may be the beginning of a periodical enlargement of the channels due to causes for which no analozy can be found on the terrestrial globe.-The ancient geography of Western Asia elucidated by means of the cuneiform inscriptions, by M. Delattre. By a careful study of the itineraries and warlike expeditions described in the Assyrian and Babylonian records the author endeavours to determine the position of numerous localities unknown to the Greek and Latin writers. - The origin of the Flemish people, by L. Vanderkinden. In reply to M. Wauters' recent memoir, the author shows conclusively that the Saxon and Frisian elements are largely represented in the present populations especially of Western Flander's.

Rivista Scientifico-Industriale, October 31.-Paramagnetism and diamagnetism, by Prof. Carlo Marangoni.-On the velocity of the rays polarised round the interior of a body endowed with rotatory power, by Prof. Augusto Righi.--Experiments on the heating of boilers with petroleum, by the editor.--On the native arsenic of the Valtellona district, by $\mathrm{D}$. Bizzari and $\mathrm{G}$. Campani.

Fendiconti del Reale Istituto Lombardo, November I2.Critical and exegetic essays on the sources of Roman jurisprudence, by Prof. C. Ferrini.-Theoretical treatment of the question of the ventilation of rooms, showing that in all cases the ventilating apparatus should be placed above, by Prof. R. Ferrini.-On a question of priority of discovery in bacterio-therapeutics, by E. L. Maggi.-Analytical functions of a single variant with any number of periods, by $\mathrm{E}$. F. Casorati.Meteorological observations made at the Brera Observatory, Milan, during the months of August and September.

\section{SOCIETIES AND ACADEMIES LONDON}

Royal Society, December 17.- “An Experimental Investigation into the Form of the Wave-Surface of Quartz," by James C. McConnel, B.A. Communicated by R. T. Glazebrook, M.A., F.R.S.

The paper contains an account of a number of measurements of 